\title{
SOME ASPECTS OF EXTRADURAL EVOKED POTENTIALS IN MAN
}

\author{
By \\ TsuTomu MATSUZAKI \\ From the Department of Oto-Rhino-Laryngology, Faculty of Medicine, \\ University of Tokyo (Director: Prof. I.Kirikae)
}

In five subjects with chronic otitis media or middle ear anomaly, a silver-ball electrode was inserted in the extradural space through the temporal bone in the middle ear surgery, and auditory evoked responses from the extradural electrode were observed by an average response computer.

In spite of remarkable individual difference the typical waveform consisted of three or four components of which the first one appeared at the latency of appreximately $40 \sim 50 \mathrm{msec}$. and its full time course amounted to $250 \mathrm{msec}$.

The amplitude of the extradural responses showed five to six times as much as the response simultaneously recorded on the scalp.

The features of the extradural responses were discussed from the previous works in depth electro. encephalography.

\section{頭皮上及び硬膜上より誘導した脳波聴性反応の観察}

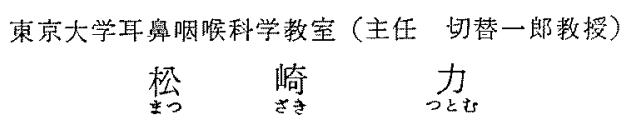

\section{第1章 緒 䚻}

1939 年 Davis, P.A.1) 及び Davis, H. et al ${ }^{2}$ が人 間頭皮上より音響刺激に対する誘発反応を記録して以 来，この事象に閶して多くの検索が行なわれている.

近年，この誘発反応をより明確に観察するために電子 加算機がこの研究に媊入され，反応が平均波形として得 られるようになつた。それによりこの領域の検索は格段 の進步を示した。また，一方この脳波聴性反応を他覚的 聴検の指整とせんとする試みが Doerfler ${ }^{3)}$ (1948), Tato4) (1949) らにによつて示晙され, 以後非常に多くの 業續がその分野に括いても集積されている。

しかしながら，それらの諸知見に拘らず，脳波聴性反 灾の個々の波形成分及びそれらの本態，起源，さらには 聴覚との関連性について諸家の間で細部に亘つては一致 をみていない，ごく最近，Bickford et al9) (1964)は 本誘発反応波形の早い成分忹竻原性のものであるうと推 論し，それに対し，また義論がなされている。

我々は今回，人間の頭皮上及び硬膜上より脳波聴性反 応を同時誘尊，電子加算機を利用して平均波形として記
録，各成分の性状について，三の知見を得たので，こ こに報告し大万の御批判を仰ぐ次第である。

\section{第 2 章 研究方法}

（1）被検者は第1表の如き中耳故形及び慢性化膿性中 耳炎の衍後患者を対象とした．可及的に一侧耳聴力正 常，他側高度難聴者を選び，患侧耳手断後に上敬室の上 方約 $1 \mathrm{~cm}$ の部位の 側頭骨に直径約 $7 \mathrm{~mm}$ の穿孔老設 け，その部位上り前上方に向つて頭蓋骨之硬脸膜間を虽 離, 電極を挿入した。

予め, 患者の承諾を得, 原則として術後 1 日目に検查 を施行し，後直ちに筐極を技去した。いずれの崔例にも 電極搜入による後遗定は誌められなからた。

(2) 硬膜上活皆電極仕長さ的 $20 \mathrm{~cm}$, 值径 $1 \mathrm{~mm}$ の銀 線の先端に直佳約 $1.5 \mathrm{~mm}$ の銀球体の附着したもので, 銀線の部分はポリエチレン管で被覆絶緣されている。

頭皮上誘導電極仙脳波用針電極を用いた。

（3）硬膜上誘導電極の位置は術後X線写真撮影で確認 した。第 1 図に示す如く，各萑例とも多少の相違はある が，すべて側頭葉外側面硬膜上に電極が位置していた。 
第 1 图行被众者の硬脱上電極の位䍛

上段レ楾写宾は症例 3 の位置を示与
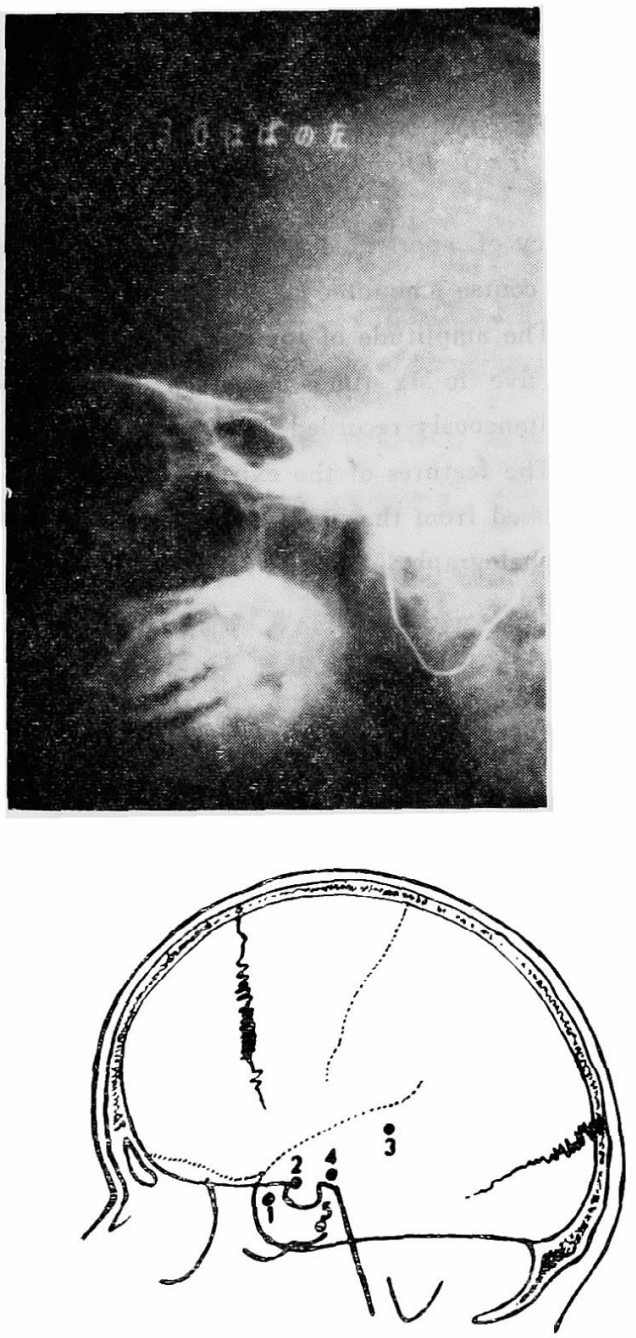

頭皮上脳波は硬膜上電極の真上と思われる部位より誘 導した。それはほぼ中側頭部誘導に相当した。

不関電極を前頭部（針電極）に置き，原則として硬膜 及び頭皮上から双極誘導した。鼻背部に平板電極をあて 接地した.

（4）刺激音としてはオージオメーターよりの純音 $(0.5,0.8,1,2 \mathrm{KC})$ を用小, 各被検者の閾値上 $30 \sim 80 \mathrm{~dB}$ の強さでスピーカーより与えた.

被検者は暗い防音電気遮蔽室内に安静仰臥した，多く の場合，検査開始後間もなく被検者は浅い睡眠状態とな
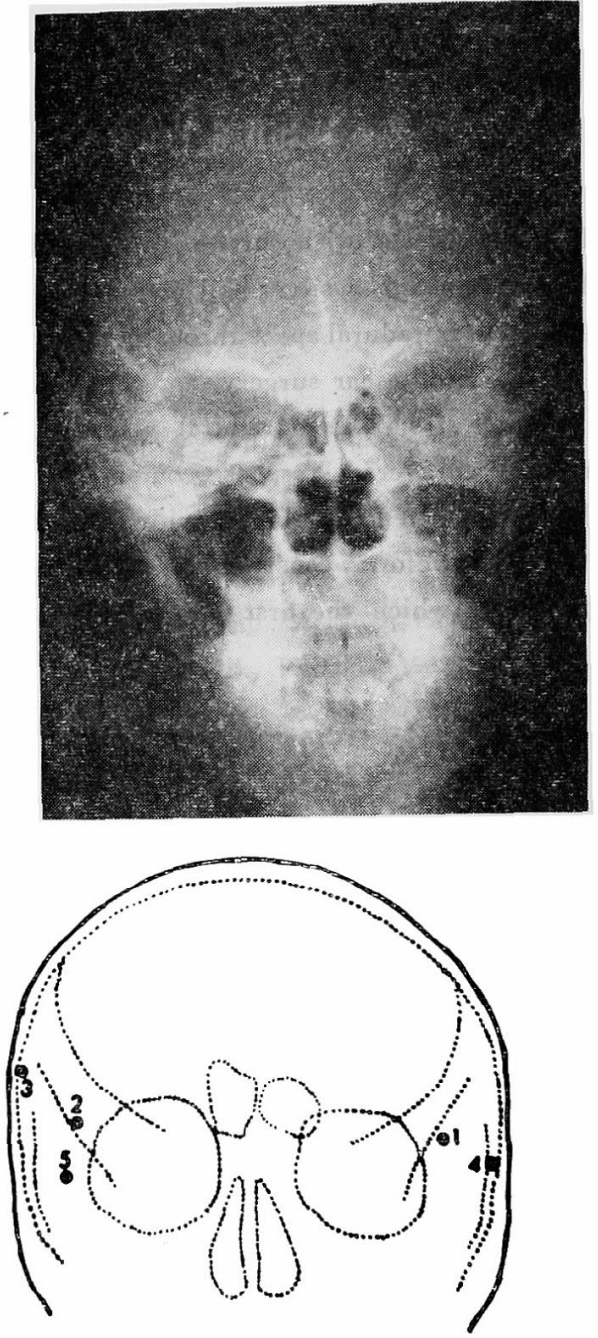

ることが観察及び脳波上に認められた.

音響刺激は立ち上り下り 10 ミリ秒，持続 100 ミリ秒 に電子管スイッチで切断し， 1 2 秒に 1 回の頻度で 40 $\sim 50$ 回周期的に与光た.

（5）頭皮及び硬膜上よりの脳波は三栄測器製 801 型万 能記録計に記録し，その一部を脳波誘発反応用加算機に 誘導，脳波反応を加算ささせた．加算結果を再び万能記録 計に戾し，描記させた。

また，加算反応を同時に㓌極線オッシロスコープに脬 導観察すると共に, 長時間記録カメラによりその一部宛 
第 2 図 Blockdiagram

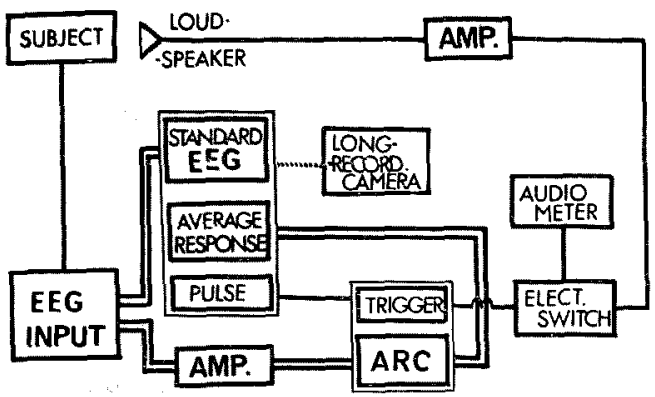

記録撮影した。

上記のブロッタダイアダラム第2図にホす。

第3 章 研究結果

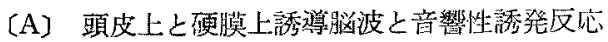

第3 図は中側頭部一前頭部双極誘導による㲅膜上及心゙ 頭皮上脳波を併記したものである。

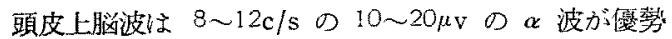
で，時に $20 \mathrm{c} / \mathrm{s}$ 前倦のさらに低電位の速波が持续する。 通常側頭部脳波所見である.

これに対し，硬膜上よりの脳波は同桖 $10 \mathrm{c} / \mathrm{s}$ 前後の $\alpha$ 波が主体をなすが，道常それらは高笔位であり50〜70 $\mu \mathrm{v}$. 時には $100 \mu \mathrm{v}$. を越古る振幅を示すものも認められ

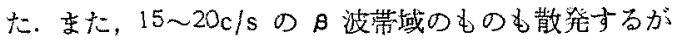
それらは比較的電位が小さい傾问が見られた。

全般的に雨者を比較すると笔位に放いて硬膜上脳波は 頭皮上よりの4〜5偕，稀比10倍飞達する值を示した。

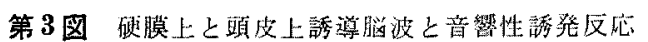
音製刺激 $1 \mathrm{KC}$ 闕值上 $50 \mathrm{~dB}$

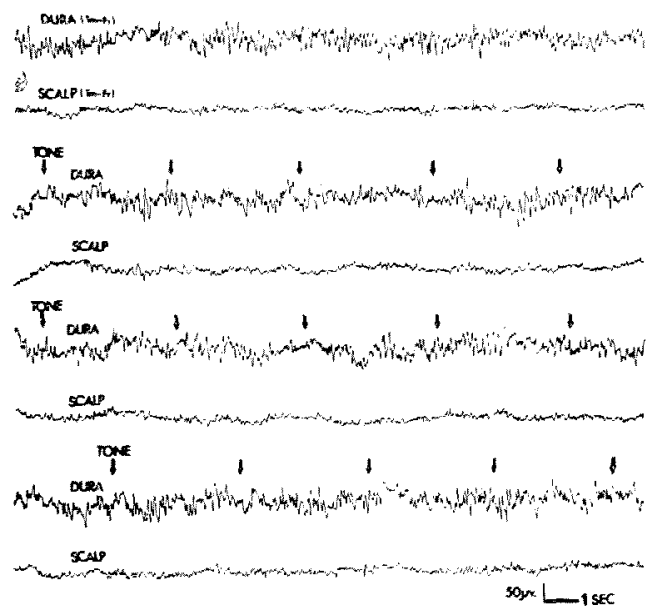

次に周波数については前者が高振幅のため一見速波攧问 の如く思放れるが，弪体をなす $\boldsymbol{\alpha}$ 波带域ではほぼ同期 している、しかし，さらに速い䦌波数成分については硬 膜上侤導の万がやや優勢のようである。

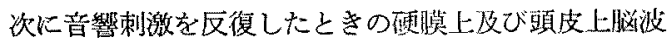
の反応を観察するに，第 3 図中 2 行目 2 番目、4番日， 3 行目 2 番目，4行目 2 番目，3雒目に見るよ5に硬膜 上脑波に誘発反応と思わ机る電位罗動の認めら饥るもの むあるが，多くは㽞電位の自発脳波のために明傕でな w.

一万，蹎皮上脳波では同剌激に执いて詳絸に梌系すれ ば二，三の誘発反広を認め得るが，なお明らかでない。

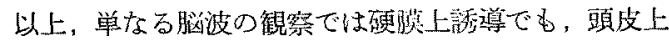
誘導でも，S/N 比に関して一疗一短であり，绫発反応 は見出し難い。

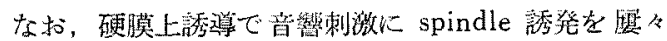

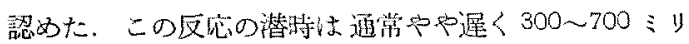
秒であつた。

(B) 平均加算法に上る頚皮上及び硬膜上脳波の 音響性誘発反応

(1) 誘発反応の加算発達過程

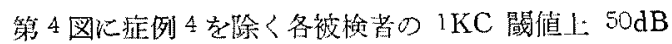
の刺激に対寸る反応の出珪様式を硬慔上と頭皮上とを刘 比して示す。

反応波形の成長過程は明らか心硬膜上禖道に打いて影 著で，既に10回加算で明瞭な反心が得られることが多 いしかしながら，本誘導では自然脸波電位が大なるた わ比較的早い加算回数に和いて区応波形がそれらに䧣澈

第4图各被檢者における相膜上及び顒皮上 誘発反応の発逵過程の比校

\begin{tabular}{|c|c|c|c|c|c|c|c|c|}
\hline Not & \multicolumn{2}{|c|}{1} & \multicolumn{2}{|c|}{2} & \multicolumn{2}{|c|}{3} & \multicolumn{2}{|c|}{5} \\
\hline 0 & $1 \mathrm{KC}$ & $50 \mathrm{~dB}$ & $1 \mathrm{KC}$ & $50 \mathrm{~dB}$ & $1 \times c$ & $50 \mathrm{~dB}$ & IKC & $50 \mathrm{~dB}$ \\
\hline$m_{b}$ & dura & scolp & dura & scolp & duro & scolp & duro & scolp \\
\hline 10 & $x+x-3=m$ & & $x-m=$ & & . & - & 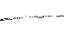 & \\
\hline 20 & $m$ & & $k-m$ & wha & $\cdots$ & $\ldots$ & W & \\
\hline 30 & & 2 & Nomenn & $A$ & wastr....... & $x$ & $m-2$ & tor....... \\
\hline 40 & s & s. & Wratum & $N$ & Motherm & & throvin & then \\
\hline 50 & mons & & 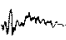 & $m$ & & N" & 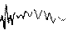 & 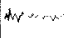 \\
\hline
\end{tabular}


されてしまらこともあつた。また，滈電位の $\alpha$ 波が持 続すると波形が桨化してしまら例も見られた。

一方，頭皮上誘導では反応と判定し得る波帅は少なく とも20〜30 回加算しないと出琴しなかつた。

両誘導の波形については興型的症例では本質的相違は 認められなかつた：通常50回加算結果で硬膜上反応の 最大振幅は $500 \mu \mathrm{v}$. 頭皮上反応のそれは $150 \mu \mathrm{v}$. で前者 が約3〜5 倍の電位に発達している.

次に, 誘発反応の聞値に関しては硬膜上誘導では閶值 上30dBでほとんど全例に加算反心が見出されたが，頭 皮上誘導では同じ強さで50 回加算結果でる 各半数例に 区応を認め得なからた。

頭皮上腷波に反心成の認められた全例に硬膜上脑波にも 反応が検出できたが，両者の反応闒值差恪各被検者に上 り哄なり 15 30dB と推定された。

（2）硬膜上誘導に上る加算波形

加算波形には著明な個体差があり，また同一被㛟者に 和いても検查中に種々に変化することがあつた。

第 5 図に硬膜上より誘導した典型的波形を列挙する。

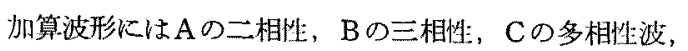
さらにDの如き楝状波が見られた。

第 5 図硕膜上浮発反灾の典型的没形例

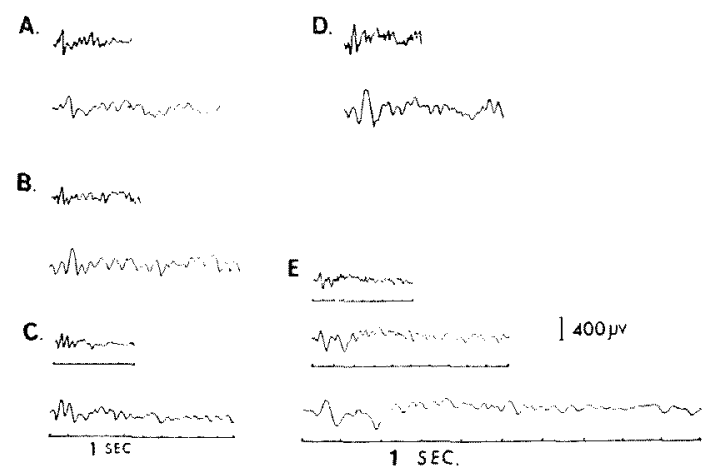

加算波形の各成分の潜時火ついてはEの早迷りから推 筧するに埐初の側頭部陽性の小さい波の最大振幅潜時 は40ミリリ秒に相当した，続く大きな隍性波注約 65 ミリ

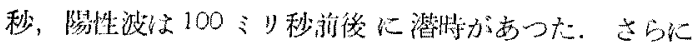
荤い波の成分がそれに統き全絽過は約 250 ミリ秒儿達し た.

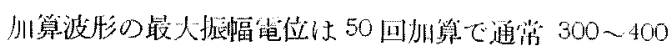

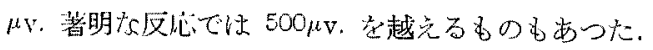

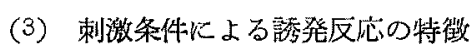
第6 図は症例 4 の各種音響刺激下に敌げる誘発反応を 頭皮上と硬膜上とで対比したものである.

各隹波数は加算反応の出現に汪とんど影鄉せず，また 反応波形とも特に関係が認められなからた。次に刺激の 強さでは $30 \mathrm{~dB}$ と $50 \mathrm{~dB}$ とで特に相違は認められなか つたが，闖值上 $30 \mathrm{~dB}$ 以下では硬膜上誘導に和いても 反応電位は著明に減少した，刺激の強さと反応電位との 間には間值上 40〜 50dB 附近まで一次的関係が見られ たが，波形々強さの間には何ら特異的関連が認められな からた。

上記の結果は他の被検者にもほぼ共通した知見であつ た。

第 6 図各刺激条件下の謤発反応 50 回加算結果の比鄣

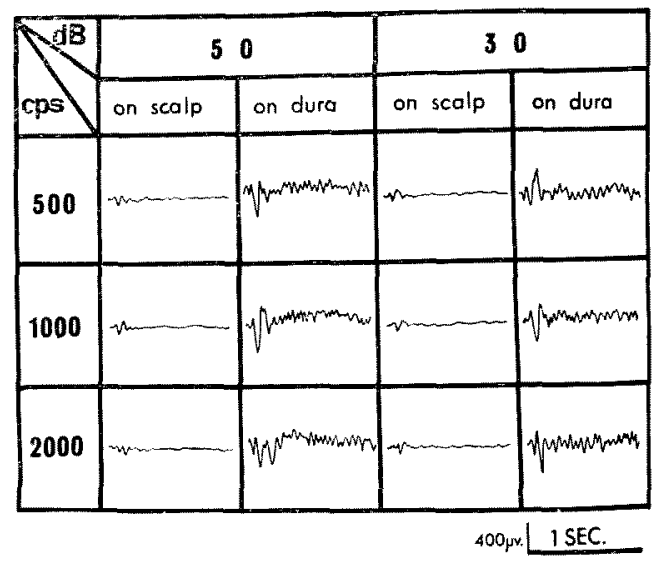

第 4 章 総括並びに考按

1939.年 Davis $5^{122)}$ が人間頭皮上より音響刺激誘発 反仙を㴭察して以来，その現象は二つの方面に执いて多 くの检索がなされて来た。 その一つは大脳生理機構解明

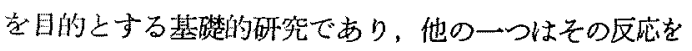
他覚的聴検, 特に紀児聴検の指標として臨床的に応用せ んとする矿究である.

しかるに，本誘発区応はその電位が小さく，通常の状 態では大きな自発脳波に隠蔽されて認め難い，このため いくつかの記録を刺激特点を一致させて重权合わせた り，脳波電位を代数的に加算したりする方法が考案され た.これによれば，全く不規則に出現する自発脳波は正 㭥相殺されて零 (甚線) に近つくに刘し，制激时点加

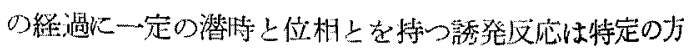


第 1 表 被検著一覧表

\begin{tabular}{|c|c|c|c|c|c|c|}
\hline UE & 例 & 年令 & 別 & 疾患名 & 術 & 側聴 J \\
\hline & & 16 & s & & $\begin{array}{l}\text { 中 耳 } \\
\text { 根治手術 }\end{array}$ & \\
\hline 2 & & 22 & of & 道 & & \\
\hline 3 & & 20 & $\delta$ & & $\begin{array}{l}\text { 鼓室班 } \\
\text { 泪 }\end{array}$ & \\
\hline 4 & & 46 & o & & 根治手 & ㄴ- \\
\hline 5 & 3.3. & 40 & & & $\begin{array}{l}\text { 中囥 } \\
\text { 根治手術 }\end{array}$ & 軖度障害 \\
\hline
\end{tabular}

向に加算され成長し，明膫な波形として発現することに なる。

この操作を電気的に行なう初期の試みは Dawson ${ }^{6)}$ (1954) に上つて報告されたが, Brazier et al7) (1956)， Barlow ${ }^{8}$ (1957) らは電子加算機を用いて誘発反応を観 察した.

その後 1958 年, Geisler et al ${ }^{9)}$ は, 人間の頭皮上よ りの聴性反応を初めて加算波形として観察，その反応間 值から他覚的聴力闒値が測定し得ることを示唆したが， Lowell et al10)11) $(1960,1961)$ は加算波形に上る闒值 測定を詳細㰸索した。

さらに最近に至り, Bickford et al 12) 5)(1963, 1964), Williams et al 18) (1963), Borsanyi 14)15) (1964 a.b.), Cody et al 16) (1964), McCandless et al 1i) (1964), Derbyshire et al 18) (1964), Goodman et al 19) (1964) らが陸続としてその業績を発表し，本邦に拁いても戸榢 $5^{20)}$ (1963), 鈴木ら ${ }^{21)}$ (1963), 吉江 ${ }^{22)}$ (1964), 田 口 ${ }^{23)}$ (1964), 松崎ら 24) (1964)，鳥山5 25) (1965) が 各種電子加算機を使用してその成綪を発表している.

しかしながら，既述の如くそれら業績にも拘らず，諸家 の報告の間には本誘発反応の波形，潜洔さらにはその本 態関して完全なる見解の一致をみていない，脳波聴性 反応が他覚的㯖検の指標として臨床的に応用されるがた めにはその本態汇関してより確然な基磷的研究がなされ なければならない，今回の研究成續はその観点において 誘発反応の解明の一端沈示唆を与えるものと思われる。

以下, 前章の研究結果について従来の諸業績に贸らし て考察を加えてみる。

\section{(A) 硬膜上脳波とその誘発反応}

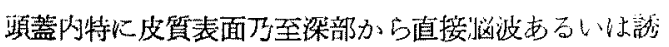
発反応を誘導する研究は古来多く奏駼動物儿拈いて行な
われて来たが，人間を刘象とするものではいくつふの制 約があつた。

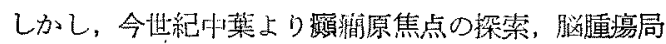
在の臨床的要求，あるいは大这些睤内及び皮質下構造の 機能を神経生理学的に解明せ几とする努力は深部電極法 26)の活用となり,さbに Bickford et al 27) (1953)の 先駆的策續以来人閌大脱の慢性植入電極法になで発展し ている.

さて，通常皮質脳波についてその特徴を彷来の記载上 りみるに，中心满附近，特に吣心前回には振幅 $50 \sim 100$ $\mu \mathrm{v}$. 前後の速波が漸続出現し， $\alpha$ 波に乏しい. しかし， これより後方，中心後回，頭項部に向からにつれて 10

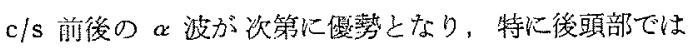
$\alpha$ 波の振幅がもつをも大さくなる，また，側頭部の $\alpha$ 波 は頭頂部，後頭部のそれに比し振幅が小さく不規則であ る.これらの報告は我々の各被㭘者の硬膜上脳波の所見 とよく一致していた。

次に，硬膜上脳波を頭皮上脳波上比較してみるに，前 者は電気的活動の発生部位により近葌しているからその 電位振幅がより大であることは当然である．脳波の発生

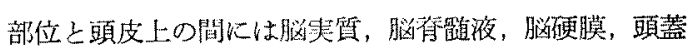
骨、頭皮の各層が分在しておら理論的には先のいずれに 扎いても咟位の減衰が生じらる。

大脸の麗位起源上頭皮上電位の間の関係を定量化する 試みは模型䒜驗でまず行なわ礼た。即ち，Brazier 28) (1949), Frank 29)（1952）証均等な伝導性を有する物質 の球体の中に露気的双極体を入れた模型で球体表面電位 を湘定し，Geisler et al 30) (1961) は同様の球体とを

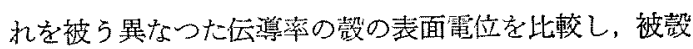

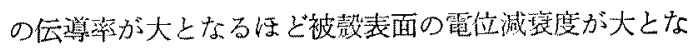
ることを明らかにしている。これは Cobb et al ${ }^{31)}$ (1960) が一側大脳半球剔除術後患者で患側の路液の半 分を空気で置換して脳波検盀を行ない，瞋液上の頭皮か らの電位がより小であるといら報告とも一致している.

しかしながら，笑際人间脳波の場合は上り複雑であ る。それに関与する各層媒体の伝導性については皮質の 抵抗が骮液の䄪 5 倍，白啠が皮睤の約 1.5 倍の抵抗が知 られている位で，硬膜，頭蓋，頭皮に関して信頼すべき 値の報告がない

たた，臨床経験的には皮質頭皮間の䉓位の比を Brazier ${ }^{28)}$ (1949) は6 8: 1, Penfield et al ${ }^{32)}$ (1954) 小 約 10:1, Sem-Jacobson et al 33) (1953) 㑐2:1, Abraham et al $\left.{ }^{34}\right)$ (1958) (45 6:1, Geisler et al ${ }^{30)}$ 
(1961) は3:1, Giblin 35) (1964) は3:1 と述へてい る、我々の研究では硬膜上の誘導であつたが，平呁4〜 5 倍の電位の墫加が観察されている。

次に，大脳表面乃至深部誘導の語発鼠位について考察 する、樑部電極に誘発反応の検索は先ず光刺激で Gastaut ${ }^{36)}$ (1949) に上り初めて報告さ机ている。彼は人間 の䙺放線から光儿対する誘発反応を求的，その反応様

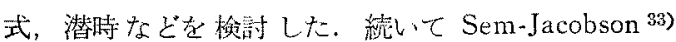
（1949）同じく視放線附近から光刺湤に对する明確な

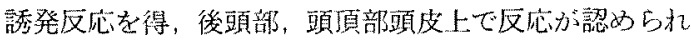
ないときでる 深部誘導で 見出しうることがあるという Gastaut ${ }^{36)}$ (1949) の知見を確認している.

一力，音響刺激に対寸る誘発反店を人間大脳聴皮質引 ら誘県した業績は洗悦し得大限り今日迄 Chatrian et al ${ }^{3 i)}$ (1960) のそれが唯一のものである，彼等は外側 大脸裂の樑部に電極を挿入，クリック刺激に対する反応 様式を観察した。これに対し，山本ら ${ }^{38)}$ (1958) は皮質

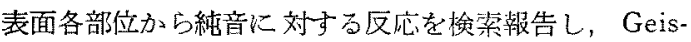

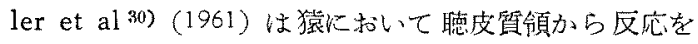
誘導した.

他方，人間体知賞皮質領はその容易心到達し得方局所 的関係加誘発反応の研究は比較的多々, Jasper et al 39) (1960), Hirsch et al 40) (1961), Domino et al 41) (1964), Giblin 35) (1964) 5がその検討を行なつてい る。要た，これらの研究者の多くが笔子加筧機を利用， 反応を平抣波形として観察していることは注目に価寸 ๖.

(B) 硬膜上新発反応の性状汇閔する考察

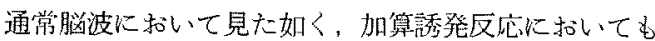
硬膜上では頭皮上哜算よりる明らかに大きな電位として 出現した。

今，その電位差を雨者に执いて比較すると，自発脳波 とほ活同様5～6倍の值を示した。一般に誘発反応の㛟 出に加算法を応朋する日的吉 S/N 比の改善にあるので あるが，上記の事學は $\mathrm{S}$ (誘発反応) のみならず，N (自発脳波)まで增大しているので加算法を試及てる筆 に全体の電位を增幅記録させた結果にしかならない、確 か炕記録電位が大となれば観察が容易となるが，それの

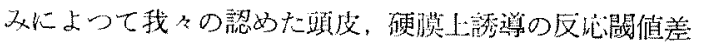
15〜30db が説明し得るのであるらか. こ机は硬膜上誘

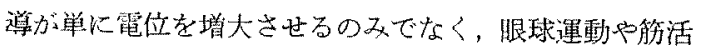
動，頭の動きなどによつて起される人工的障珰（N成 分）を殆えと除くことができる利点によるものと思われ
3 .

さて，硬膜上誘導の際の誘発反応霆位の減垜について は最近，Domino et al 41) (1964) は体知覚領からであ るが頚蓋と頭皮が著明に電位を減少せしめたと述べ， Geisler et al 30)（1961）は頚蓋罥は反応霓位を減衰せ しめなかつたが，頭皮成分がそれに著しく関係する知見 を報告している，また，與味深いのは前側頭部に限局し

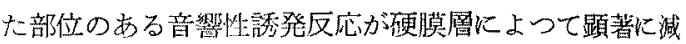
竟することを見出している。これは我々の硬膜上誘導に

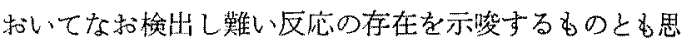
われる。标た，Geisler et al ${ }^{80)}$ (1961) は諉発電位に 打いても伀尊浡の大なる媒体で減衰度が大きいことを指 据している。

Abraham et al ${ }^{34)}$ (1958) は瀕翡患者慆波に見られ る発作性放電が頭皮上誘導で险性であつても去の発生部 位は必ずし名静此状態にあるのでなく，その放電の大き さと皮質分の厇さとの関係から湏皮上では娍言し認めら れなくなるとしている。さらに，彼らは頭皮上電位に影

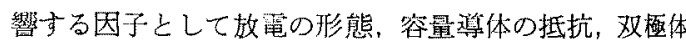
の方向の変動，二次的活動電位の出現などを挙け゚てい 3

次に，硬膜上誘発反応の波形については Domino et al 41) (1964) は体知覚刺激で四相性反応る記载している が，同刺激で注頭皮上諲導のみならず，皮質上に拈いて む比較的一致した反应波形が陚明されている，即ら，頭 皮上からは Allison 42) (1962), Goff et al 43) (1962) らが潜時約 16 ミリ秒から 220 ミリ秒炕亘る変動を梁め， それを5つの成分に分類しなが，皮望上からは Jasper et al ${ }^{39}$ ) (1960) が潜持約 18 ミ リ秒の誘発反応を観察, 最近 Giblin ${ }^{35)}$ (1964) は潜時 20 30 ミリ秒の初期陰陽 波とさらに遅い陰陽波（40６0ミリ秒）を報告した。 以

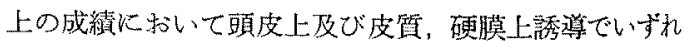
も 20 ミリ秒前後の一次反応と思われる電位が観察され ていること，また，乙の反応波形が各誘導ではぼ類倾し ていることは注目に值する. Domino et al 41) (1964) は頭皮上誘導と福膜上誘導の波形は之の電位発生火充分

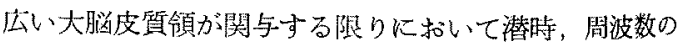
翌化を受けないと述へているが，上記の琴象は体知覚領

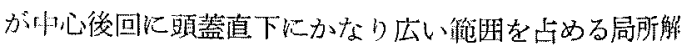
剖学的関係に依存すると思呩机る。

その点に関して人間聴皮質領は知賞領と大分趣を異仲 する。第 7 図に見る如く一次聴覚領と見做される部位出 外側大䍙裂 (Sylvius 裂) の深部の横側頭回 (Heschl 


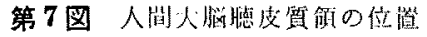

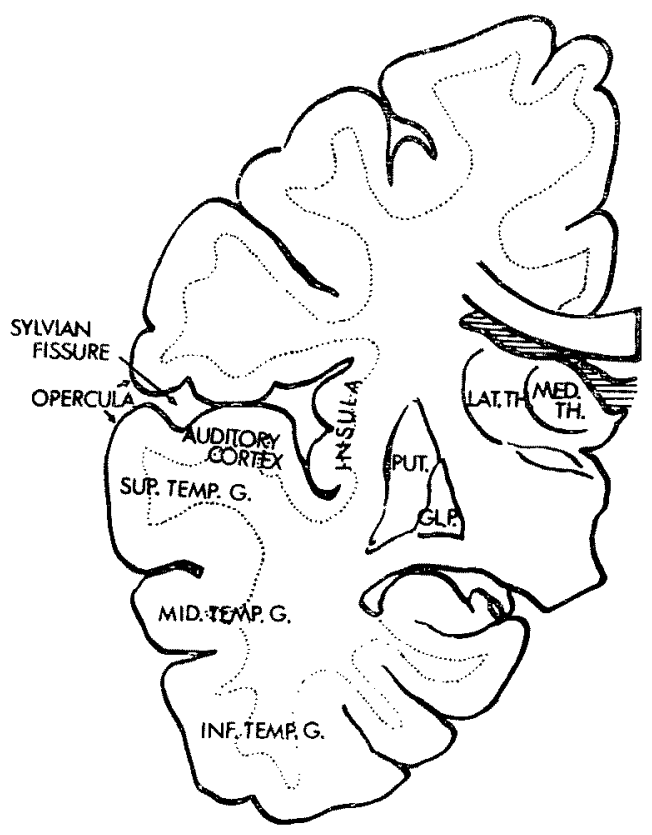

回）にあり，しかも平沢 44) (1950)に上ればその面䅡 は一側大脳半球で $3 \sim 4 \mathrm{~cm}^{2}$ に過ぎず。大脳表面積の約 300 分の1にしか相当しないといら。この事然が人間聴 皮質領から一次反庒を誘尊することを難しくしていると いえよう。

実際，人閒の聴皮質に直接電桠を插入した柴績は Chatrian et al 3i) (1960)にみるのみである。彼らは単 一クリックに対する誘発反応として8〜24 ミリ秒潜時の 小さい $(30 \mu \mathrm{v}$ ，以下) 隍性波, 続いて $25 \sim 30$ ミ》秒潜時 の陽性波 $(40 \sim 50 \mu \mathrm{v}$ ) ，65 130ミ》秒潜時の险性波 $(60$ $\sim 80 \mu \mathrm{v}$ ) $90 \sim 175$ ミリ秒の陽性波 (50 $\mu \mathrm{v}$. 以下) を認め, 全経過は凡そ190〜280ミリ秒であつたと述べた。彼ら の得た最初の变動は明らかに一次聴覚反応と思われる が，未だに追試した報告がない。

さて，頭皮上音響誘発反底を加算波形として初めて観 察した Geisler et all 9)(1958) は約 30 ミリ秒潜時の装 動を認め三次反応であららと述へ，一次反応はその解剖 学的関係から頭皮上から誘導することは不可能と推論し た. その後, Lowell et al 10)11) $(1960,1961)$ も約 25 ミリ秒潜時の早い反応を検出しているが，最近 Bickford et al 12)5 (1963, 1964) は20 30ミリ秒潜時の早 い反応成分は皮質笔位でなく頭皮の矣原性の電位である といら見解を発表している.
その主張は Borsanyi et al ${ }^{15}$ (1964 b), Cody et al

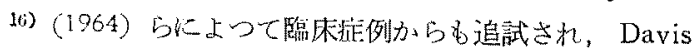

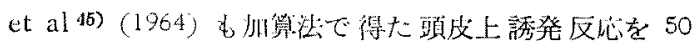
ミリ私潜侍を境に二群に分け，それぞれの特徽に相違の あることを述べたが，Derbyshire et al 18) (1964) 女音 響性誘発反応成分の記述統一のために提胆した標集波形 の中で50ミり秒潜時以前の記載を侗早として擗けてい 子.

我々の今回の硬营上绫導では40〜50ミリ秒潜時の成 分が最子早いもので，それ以前以は明らかな变動は認め

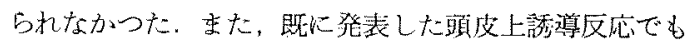
同様 40〜50ミリ秒以前の多檕は碓認されていないので, 両者の比較において是い成分が舫原性であるか否か快 定し難いが，少くと\&40〜50ミリ秒潜㭙の初期謷動が 硬膜上においても誘導しえたことはその皮質起源を䇺明 し得たといえよう。

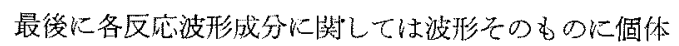
差が多く 統一した記载が難しいが典型的波形では $\mathrm{P}_{1}$ 45 ミり秒, $\mathrm{N}_{1} 70$ ミリ秒, $\mathrm{P}_{2} 100$ ミり秒, $\mathrm{N}_{2} 150$ ミり 秒であつた，各成分の意義については後述する，なお， 頭皮上誘発区心亡比へ硬膜上よりのそれは波形がやや䗲 状を旺するのが特徵であつた。これは頭蓋. 頭皮が一種 の容量抵抗系を形成し，波形の CR 时定数に影響を与 点たものと思われる。この効果加硬膜上の誘発反応検出 をいくら゙ん容易にしたとも考えられる。

(C) 硬膜上誘発反応の本態に関与る考察

頭皮上で音響性誘発反応を初めて 観察した Davis et al 2) (1939) は 100 ミリ秒潜時の遅い反応を既に動物に おいて諗められていた二次反応に相当すると考察, 後年 Geisler et al 9) (1958) も音響刺激に対与る加算波形加 二次反応であると推定した。これに対してその発生機序 に関しては Gastaut ${ }^{46)}$ (1953), Roth et al 47) (1956) 怯原始的感覚機棈を想定，Larson 48) (1956) は警愕反 応との関連に执いて論じている。

最近 Bickford et al 12) (1963) は音響刺激により全 身筋系に反応の生ずるのを諗め，これを audiomotor system と呼んだが，頭皮上で観察される誘発反応の早 い成分の皮質起源比疑問を抱き，筋原性であると主張し た. Bickford et al 5) (1964) の見解の根拠は反応潜時 の短かいこと, 頸筋の繄張状態に上り反広電位が变化す ること，クラーレ投与で反応消失することなどであつた が, Borsanyi et al 15) (1964) もこれを追陚確認し， Bickford et al の見解を支持した。 また, Cody et al 


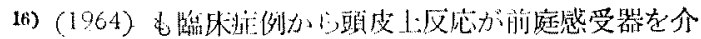
した筋反店電位であるとい Bickford et al 5) (1964) の想定家実証した。

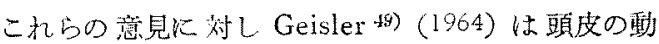

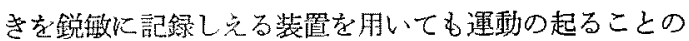
証明されてかかたことを述べ，音響刺湤の感受器は前庭 以外方考之られると反部している。交た，Barlow ${ }^{50}$ (1964)は Bickford et al 5) (1964) に上り㿥察された 誘発電位は梅紡錘から生じたものでないかと推論，それ

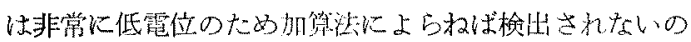
であるうとしている。

その他，早い成分の起源としては蝸牛劣るいは迷路の 電位の漏洩とするるの，詮索反射とするもの，各種笔位 の混合とするものなどの諭争があるが，我々の硬膜上誘 導法では 40 ミリ秒以前の反応は認められず 今後检討 の問題であるう。

次に，30〜40ミリ秒以後の誘発反応については体知 覚反応であるが，Allison 42) (1962) が反応灰復函数か b, Goff et al 43) (1962) は区応分材上加 550ミリ秒 前後の反応成分を連合領反応，65２20ミリ秒のてれを 非特異的誘発反応と分類した。この教察を聴覚反心に類 推するならば，我々の得た 40〜65ミり秒潜時の成分は 連合領反応に，艺机に続く崌く緩やかな反応は非特異的 反応, 即ち Davis et al 2) (1939) のい5 K-complex に相当するものと思われる。さらに，推測するならば， 前者即ち連合領反応とは Penfield et al 51) (1959) が 述べている一次聴皮質に隣接して側頭葉の広沉な部位を 占める聴覚に関連した統合作用領の活動部位の表現され たものであろう。

最後に, 今回の研究の䦓題と今後の課題を考察する と，本研究に扎いては硬膜上でしかも側頚葉外側面から の誘導であつたこと，さらに早い潜時の反応成分が認め られなかつつたこが問題となつた，今後の課題としては 側頭葉の聴皮質から直接反応を記録寸ること，また，頭 頂部からも同时誘導し，非特異的誘発反応 (K-complex）と聴覚との関俰を追究することであるう.

\section{第 5 章結語}

一側耳正常㯖力を持つ被检者 5 名を対象とし，側頭葉

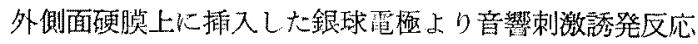
を誘導観察した。

硬膜上誘発雪位は頭皮上のそれに比べ約 5〜6倍の大 きさを示したが，波形，潜時には雨者の間に本質発相違 は熟的れなからた。

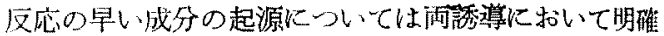
た略動が得られなかつたので結論が下せなからた。

両誘樽による反応出現の閶值差は 15〜30 dB であり，

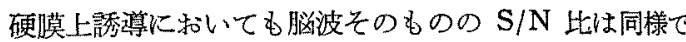
あつたが，硬膜上誘導では頭皮上のそれに比し反応の検 山が容易であつた。これは本誘導法により眼球あるいは 頭の動き，頭皮筋活動などの副次的成分が取除かれたた めと思加る。

\section{文献}

1) Davis, P.A.: Effects of Acoustic Stimuli on the Waking Human Brain. J. Neurophysiol., 2: 494, 1939. 2) Davis, H. et al: Electrical Reactions of the Human Brain to Auditory Stimulation during Sleep. J. Neurophysiol., 2 : 500, $1939 . \quad 3)$ Doerfler, L.G.: Neurophysiological Clues to Auditory Acuity. J. Speech. Hear. Dis., 13: 227, 1948.

4) Tato, J.M.: Electroencephalographic Auditive Threshold. Acta Otolaryng., Suppl., 78: 151, 1949. 5) Bickford, R.G. et al: Nature of Average Evoked Potentials to Sound and Other Stimuli in Man. Ann, N.Y. Acad. Sci., 112: 204, 1964. 6) Dawson, G.D.: A Summation Technique for the Detection of Small Evoked Potentials. EEG clin. Neurophysiol., 6: 65, 1954. 7) Brazier, M.A.B. et al: Some Applications of Correlation Analysis to Clinical Problems in Electroencephalography. EEG clin. Neurophysiol., 8: 325, 1956. 8) Barlow, J.S.: An Electronic Methad for Detecting Evoked Responses of the Brain and for Reproducing Their Average Waveforms. EEG clin. Neurophysiol., 9: 340, 1957. 9) Geiler, C.D. et al: Extracranial Responses to Acoustic Clicks in Man. Science, 128 : 1210, 1958. 10) Lowell, E.L. et al: Temporal Evannation: A New Approach in Diagnostic Audio. logy. J. Speech Hear. Dis., 25: 340, 1960. 11) Lowell, E.L. et al: Measurement of Auditory Threshold with a Special Purpose Analog Computer. J. Speech Hear. Res., 4: 105, 1961. 12) Bickford, $R$. G. et al: A New Audio-Motor System in Man. EEG clin. Neurophysiol., 15:922, 1963. 13) Williams, W. G, et al: EEG Responses to Auditory Stimuli in Waking Children. J. Speech Hear. Res. 6:57, 1963. 14) Borsanyi, S.J.: Some Aspects of 
Auditory Evoked Potentials in Man. Ann. Otol., 74:62, 1964. a. 15) Borsanyi, S.J. et al: Auditory Evoked Brain Responses in Man. Arch. Otolaryng., 73: 149, 1964 b. 16) Cody, T.R. et al: Average Evoked Myogenic and Cortical Potentials to Sound in Man. Ann. Otol., 74: 763, 1964. 17) McCandless, G.A. et al: Evoked Responses to Audiiory Stimuli in Man Using a Summing Computer. J. Speech Hear. Res., 7 : 193, 1964. 18) Derbyshire, B.J. et al: Template for the EEG Response to Sound. J. Speech Hear. Res., 7 · 96, 1964. Goodman, W.S. et al: Audiometry in Newborn Children by Electroencphalography. Laryngoscope, 74:1316，1954. 20）巨塚元吉他：加算方式による人 間脳波の聴性反応誘導について，Audiology，6：138， 1963.21）鈴木篤郎他：誘発電位加算装置による他 覚的聴力測定，Audiology，6:246, 1963. 22) 吉江信 夫: Digital 漹 Average Response Computer によ る聴覚性大脳誘発電位の観察, Audiology, 6: 140, 1963. 23) 田口喜一郎：アナログ型誘発電位加算装 置によ万他覚的聴力测定，耳喉科，36：497，1964。24) 松崎力他：Digital 型電子計算機に上る音響刺激誘発 反応闻関寸る奏験的研究，日耳鬼，67：1535，1964。

25)鳥山稳他：電子加算機に上る脳波聴性反応に関す 万実験的研究，日耳䖝，68: 196, 1965. 26) Hayne,

R. et al: Electrical Activity of Subcortical Areas in Epilepsy. EEG clin. Neurophysiol., 1: 437, 1949.

27) Bickford, R.G.: Some Effects of Barbiurate Anesthesia on the Depth Electrogram. Proc. Staff Mayo Clin., 28: 162, 1953. 28) Brazier, M.A.B.: A Study of the Electrical Felds at the Surface of the Head. EEG clin. Neurophysiol., Suppl 2:38, 1949. 29) Frank, E.: Electric Potential Produced by Two Point Sources in the Homogeneous Conducting Sphere. J. appl. Physiol., 23 : 1225, 1952.

30) Geisler, C.D. et al: The Surface EEG in Relation to its Sources. EEG clin. Neurophysiol,, 13: 927, 1961. 31) Cobb, W. et al: A Study of the Transmission of Potentials after Hemispherectomy. EEG clin. Neurophysiol, 12: 371, 1960. 32) Penfield, W. et al: Epilepsy and Functional Anatomy of the Human Brain. Boston, Little Brown, 1954.

33) Sem-Jacobson, C.W. et al: Depth Distribution of Normal Electroencephalographic Rhythms. Proc. Staff Meet. Mayo Chin., 28 : 156, 1953. 34) Abraham, K. et al; Patterns of Cortical Discharges and Their Relation to Routine Scalp Electrocncephalo- graphy. EEG clin. Neurophysiol., 10: 447, 1958. 35) Giblin, D.R.: Somatosensory Evoked Potentials in Healthy Subjects and in Patients with Lesions of the Nervous System. Ann. N.Y. Acad. Sci., 112: 93, 1964. 36) Gastaut, H.: Enregistrement souscortical de l'activité électrioue spontanée et provoquée du lobe occipital humain. EEG clin. Neurophysiol., 1: 205, 1949. 37) Chatrian, G.E. et al:

Responses to Clicks from the Human Brain: Some Depth Electrographic Obsevations. EEG clin. Neurophysiol., 12:479, 1960.38) 山本㢣他：人体大畄皮 質におたる聴喾中枢に就いて，日耳舅，61，393，1958。 39) Jasper, H. et al: Evoked Potentials from the Exposed Somato-Sensory Cortex in Man. J. nerv. ment. Dis., 130: 526, 1960 . 40) Hirsch, J.F. et al: Ftude des résponses électrocorticales obtenues chez l'homme par des stimulations somesthéques et visuelles. EEG clin Neurophysiol., 13:411, 1961. 41) Domino, E.F. et al: Simultaneous Recordings of Scalp and Epidural SomatosensecryEvoked Responses in Man. Science, 145:1199, 1964. 42) Allison, T.: Recovery Functions of Somatosensory Evoked Responses in Man. EEG chin. Neurophysicl., 14: 331, 1962. 43) Goff, W.R. et al: Distribution of Cerebral Somatosensory Evoked Responses in Normal Man. EEG clin. Neurophysiol., 14: 697, 1962. 44) 平沢與：大脳の樶高中权, 日本医墨出版，1950.。 45) Davis, H. et al: Evoked Responses to Clicks Recorded from the Human Scalp. Ann. N.Y. Acad. Sci,, 112: 224, 1964 . 46) Gastaut, H: Etude électrographique chez l'homme et chez l'animal des décharges epileptiques dites «psychomotrics》. Rev. neurol., 88: 310, 1953.

47) Roth, $M$. et al: The Form, Voltage Distribution and Physiological Significance of the $\mathrm{K}$-Complex. EEG clin. Neurophysiol., 8: 385, 1956.48 ) Larson, $L-E$.: The Relation between the Startle Reaction and the Non-Specific EEG Response to Sudden Stimuli with a Discussion on the Mechanism of Arousal. EEG chin. Neurophysiol., 8: 631, 1956. 49) Geisler, G.D.: Discussion of the Paper. Ann. N.Y. Acad. Sci., 112: 218, $1964 . \quad 50)$ Barlowe, J.S.: Discussion of the Paper Ann. N.Y. Acad. Sci., 112: 219, 1964. 51) Penfield,W. et al: Speech and Brain Mechanisms. Princeton Univ. Press, 1959.

稿を䅂るに臨み，釉始御指遒と御校閲を睗つた恩 䣷切誉一郎教授比梁謝致します。

（原稿到垔 $=$ 昭和 40.3 .29 日） 